\title{
Hiddenocysta matsuokae gen. nov. et sp. nov. from the Holocene of Vancouver Island, British Columbia, Canada
}

Pieter R. Gurdebeke, Kenneth N. Mertens, Pjotr Meyvisch, Kara Bogus, Vera Pospelova \& Stephen Louwye

To cite this article: Pieter R. Gurdebeke, Kenneth N. Mertens, Pjotr Meyvisch, Kara Bogus, Vera Pospelova \& Stephen Louwye (2020): Hiddenocysta matsuokae gen. nov. et sp. nov. from the Holocene of Vancouver Island, British Columbia, Canada, Palynology

To link to this article: https://doi.org/10.1080/01916122.2020.1750500

View supplementary material $₫$

Accepted author version posted online: 31 Mar 2020.

Submit your article to this journal $₫$

Q View related articles $₫$

View Crossmark data $₫$ 
Hiddenocysta matsuokae gen. nov. et sp. nov. from the Holocene of Vancouver Island,

\title{
British Columbia, Canada
}

Pieter R. Gurdebeke ${ }^{1 *}$, Kenneth N. Mertens ${ }^{2}$, Pjotr Meyvisch ${ }^{1}$, Kara Bogus ${ }^{3}$, Vera

Pospelova $^{4,5}$, Stephen Louwye ${ }^{1}$

${ }^{1}$ Department of Geology, Ghent University, Krijgslaan 281, S8, 9000 Ghent, Belgium.

${ }^{2}$ Ifremer, LER BO, Station de Biologie Marine, Place de la Croix, BP40537, F-29185

Concarneau CEDEX, France.

${ }^{3}$ Camborne School of Mines, University of Exeter, Penryn, Cornwall, UK TR10 9EZ.

${ }^{4}$ Department of Earth and Environmental Sciences, University of Minnesota, 116 Church St SE, Minneapolis, MN 55455, USA.

${ }^{5}$ School of Earth and Ocean Sciences, University of Victoria, PO Box 1700, STN CSC, Victoria, British Columbia V8W 2Y2, Canada.

*Corresponding author (Pieter.gurdebeke@ugent.be).

\begin{abstract}
A new dinoflagellate cyst genus and species are described here as Hiddenocysta gen. nov. and Hiddenocysta matsuokae sp. nov. from Holocene sediments in a core from the west coast of Vancouver Island (British Columbia, Canada). The genus Hiddenocysta encompasses spherical to ovoid skolochorate cysts, characterized by a gonyaulacoid plate pattern and a $2 \mathrm{P}$ precingular archeopyle. The species H. matsuokae is characterized by a granular wall and slender trifurcate processes with heavily perforated process bases. Two end members are described here based on process morphology and number of processes (Forma 1 and 2). Cyst wall chemistry is analyzed using micro-Fourier transform infrared (FTIR) spectroscopy and reveals a unique dinosporin composition consistent with a gonyaulacoid autotrophic feeding strategy.
\end{abstract}


Keywords: dinoflagellate cyst, taxonomy, North Pacific ocean, FTIR, wall composition, gonyaulacoid

\section{Introduction}

Around 360 of the $>2000$ known species of dinoflagellates are known to produce resting cysts as part of their life cycle (e.g., Head 1996; Gómez 2012a; Penaud et al. 2018). The majority of the resting cysts are organic-walled, and can be found in nearly all aquatic sediments and have been reported from surface sediment and sediment trap studies in coastal and estuarine waters of Western Canada (e.g., Dobell 1978; Kumar and Patterson 2002; Mudie et al. 2002; Radi et al. 2007; Krepakevich and Pospelova 2010; Pospelova et al. 2010; Price and Pospelova 2011; Gurdebeke et al. 2018a; Fig. 1). Several new species have been described from this region in recent years (e.g., Mertens et al. 2012, 2013; Gurdebeke et al. 2019a,b). Gained knowledge on the taxonomy and ecology of dinoflagellate cysts improves the quality of their application as a proxy for past environmental change in coastal British Columbia (e.g. Bringué et al. 2016) and biological studies that, for example, try to identify seed banks of harmful species (e.g. Gurdebeke et al., 2018a). Furthermore, in recent years, two workshops on the complex genus Spiniferites renewed the interest in spiniferate cysts (e.g., Gurdebeke et al. 2018b; Limoges et al. 2018; Londeix et al. 2018; Mertens and Carbonell-Moore 2018; Mertens et al. 2018; Van Nieuwenhove et al. 2018) and chorate and proximochorate cysts produced by autotrophic dinoflagellates in general. However, despite these improvements, some dinoflagellate cyst types from this region remain poorly understood and are left undescribed and can now be reevaluated (e.g. Dobell \& Taylor 1981).

The macromolecular chemical composition of dinoflagellate cyst walls, classically described as ‘dinosporin' (e.g., Fensome et al. 1993) has been studied most extensively on whole cysts using micro-Fourier transform infrared (micro-FTIR) spectroscopy. Dinosporin was found to consist of a diverse suite of complex carbohydrates (e.g., Kokinos et al. 1998; 
Versteegh et al. 2012; Bogus et al. 2014; Mertens et al. 2015, 2017; Luo et al. 2018; Gurdebeke et al. 2018b), with suggestions that there are differences in composition related to trophic preference (e.g., Bogus et al. 2014) and phylogeny (e.g., Gurdebeke et al. 2018b, 2019b). As features such as ribosomal DNA and in vivo and culture experiments are not available for dinoflagellate cysts in the fossil record, information from cyst wall chemistry is a welcome addition to the morphological data. However, study of more cyst taxa is desirable to further explore the utility of micro-FTIR for chemotaxonomy (i.e., a classification based on similarities in chemical structure and composition) and an increased understanding of dinoflagellate (paleo)ecology and the possibly differential preservation of their cysts (Zonneveld et al. 1997).

Dobell and Taylor (1981) documented an unusual dinoflagellate cyst type from Hidden Basin (British Columbia, Canada), which was not reported since (e.g., Mertens et al. 2018). Two intergrading morphologies were described as Spiniferites sp. 1 and Spiniferites sp. 2, and the hatched motile stages identified as Gonyaulax sp. 1 and Gonyaulax sp. 2 (Dobell and Taylor 1981). Here, morphologically identical cysts are studied from the Holocene sediments of Kyuquot Sound (Vancouver Island, British Columbia, Canada) as Hiddenocysta matsuokae gen. nov. et sp. nov. and its cyst wall chemistry is documented using micro-FTIR.

\section{Material and methods}

A total of 103 samples (UVic 15-583 to UVic 15-684; Supplementary Information Table 1) were subsampled from a 9.9 m long piston core (2012002PGC133), retrieved in 2012 by the Geological Survey of Canada $8 \mathrm{~km}$ from the head of Tahsish Inlet in Kyuquot Sound $\left(50^{\circ} 5^{\prime} 27.80^{\prime} \mathrm{N}, 127^{\circ} 9^{\prime} 2.75^{\prime \prime} \mathrm{W}, 147 \mathrm{~m}\right.$ water depth; Fig. 1). The samples were taken at regular intervals (every $10 \mathrm{~cm}$ ) in the core, with the exception of the upper $50 \mathrm{~cm}$, where $5 \mathrm{~cm}$ resolution was used. A plastic syringe was pushed in the core sediment to sub-sample $\sim 2 \mathrm{~cm}^{3}$ 
of material. The sediment is mainly olive-green silty mud. The subsamples were kept in polypropylene $15 \mathrm{cc}$ test tubes. The chronology of core 2012002PGC133 was established from five accelerator mass spectrometry (AMS) ${ }^{14} \mathrm{C}$ measurements on plant fragments or bulk sediment (Gurdebeke 2019; Fig. 2).

Sediment subsamples were treated following the palynological preparation method used at the Paleoenvironmental Laboratory, School of Earth and Ocean Sciences, University of Victoria, Canada (e.g., Pospelova et al. 2010; Price et al. 2016). After drying $\left(\sim 40^{\circ} \mathrm{C}\right)$ and weighing the sediment sample, a fixed number of exotic marker spores (Lycopodium clavatum) was added (one tablet from batch $\# 177,745 ; 18,584$ spores/tablet) for quantitative abundance estimations (Supplementary Information Table 1). To remove carbonates, samples were treated with hydrochloric acid (room temperature $10 \% \mathrm{HCl}$ ). After rinsing with distilled water, samples were sieved through a $120 \mu \mathrm{m}$ mesh and captured on a $10 \mu \mathrm{m}$ mesh nylon Nitex screens to separate coarse and fine fractions. Subsequently, the samples were treated for four to five days with hydrofluoric acid (room temperature 50\% HF) to remove silicates. Possible fluorosilicates were removed by a second round of room temperature $10 \% \mathrm{HCl}$ treatment. After rinsing with distilled water twice, the residue was sonicated for up to $30 \mathrm{~s}$ and collected on a $10 \mu \mathrm{m}$ mesh screen. One or two drops of the residue were mounted in glycerine jelly, covered with a cover slip and sealed with transparent nail polish.

Slides were systematically scanned in non-overlapping traverses at $400 \times$ magnification using a transmitted light microscope (LM) (Zeiss Axioskop 2 plus). A targeted count of 300 dinoflagellate cysts were systematically identified per slide (Supplementary Information Table 1). LM photomicrographs were produced from the same microscope using an MRc 5 (Zeiss) camera. Cysts were picked with a micropipette from the residue of sample 15-609 and were photomicrographed on a Olympus BX51 microscope with a digital sight DS1L 1 module (Nikon, Tokyo, Japan). 
Field emission scanning electron microscope (FE-SEM) images were taken from cysts picked from the residue of sample UVic 15-609 (7.2 m core depth, 9.8 ka). Specimens were first isolated from the samples with a micropipette with a IX51 (Olympus) or IM35 (Zeiss) inverted microscope and transferred onto polycarbonate membrane filters (Millipore, Billerica, MA, USA; GTTP Isopore, $0.22 \mu \mathrm{m}$ pore size). After 12 to $24 \mathrm{~h}$ of air-drying, the filters were affixed to aluminum stubs with adhesive tabs. Other specimens were subjected to dehydration and critical point drying, as outlined in Chomérat and Couté (2008), in order to prevent them to collapse during drying. Subsequently, the mounted filters were sputter coated with gold using a Cressington Sputter coater 108auto. The samples were observed with a Sigma 300 (Zeiss) field-emission SEM equipped with a conventional Everhart-Thornley and in-lens detectors of secondary electrons at 1.5 and $5 \mathrm{kV}$ located at the Station of Marine Biology of Concarneau.

For micro-FTIR analysis, cysts were manually picked from palynological residue from the core top sediment sample (UVic 15-684). The residue was ultrasonicated for $30 \mathrm{~s}$ and rinsed three times with organic solvents (methanol and dichloromethane, 1:1 by volume) and MilliQ water over a $20 \mu \mathrm{m}$ mesh-size filter to remove polar and apolar compounds that might have adhered to the cyst walls. Visually clean and empty cysts were manually isolated, placed on an Au-coated mirror and air-dried. Specimens were analyzed with a Bruker Hyperion 2000 microscope coupled to a Bruker Vertex 80v FTIR spectrometer in the Department of Solid State Sciences (Ghent University, Belgium) over an infrared range of $\sim 4000-650 \mathrm{~cm}^{-1}$. The objective magnification of the microscope was set at $15 \times$ and the aperture at $100 \times 100 \mu \mathrm{m}$. All presented spectra were recorded in reflection mode, at a resolution of $2 \mathrm{~cm}^{-1}$, and averaged over 100 scans. Data were analyzed with the OPUS $^{\odot}$ software (Bruker 2014). The presented absorbance spectra were obtained after background subtraction, atmospheric correction and baseline correction with a rubberband method using polynomes. Functional groups were 
identified based on comparison with Colthup et al. (1990) and published data (e.g., Bogus et al. 2014; Cárdenas et al. 2004; Gurdebeke et al. 2018b). Data reduction was performed as a principal component analysis (PCA) using PAST 3.2 (Hammer et al. 2001).

\section{Results}

\subsection{Systematic paleontology}

Division DINOFLAGELLATA (Bütschli 1855) Fensome et al. 1993

Class DINOPHYCEAE Pascher 1914

Order GONYAULACALES Taylor 1980

Family GONYAULACACEAE Lindemann 1928

Hiddenocysta P Gurdebeke, V Pospelova, KN Mertens and S Louwye gen nov.

Etymology. In reference to Hidden Basin (Nelson Island, British Columbia, Canada) where similar cysts were reported by Dobell and Taylor (1981)

Type species. Hiddenocysta matsuokae sp. nov.

Diagnosis. Skolochorate cyst with spherical to ovoid central body bearing gonal and intergonal processes reflecting a gonyaulacacean tabulation $\left(? 3-4^{\prime}, 6^{\prime \prime}, 5^{\prime \prime \prime}, 1 \mathrm{p}, 1^{\prime \prime \prime \prime}\right)$. Processes connected or not by crests.. Compound archeopyle consisting of $3^{\prime \prime}$ and 4", operculum free.

Remarks. This cyst was first reported by Dobell and Taylor (1981) in surface sediments from Hidden Basin (BC, Canada), whom considered it to belong to the genus Spiniferites (Spiniferites sp. 1 and $S$. sp. 2).

Comparison. Hiddenocysta's $2 \mathrm{P}$ precingular archeopyle distinguishes the genus from Spiniferites and Achomosphaera, which have a single (3") plate archeopyle. A further difference with Spiniferites is that the latter genus always has pronounced crests connecting the process bases, which are often absent in Hiddenocysta. The genus Achomosphaera, on the 
other hand, never has crests (Mertens et al. 2018). The extant genus Bitectatodinium has a similar 2P precingular archeopyle but is "without obvious surface projections" (Wilson 1973). A number of Mesozoic cyst genera have a similar general appearance and a two-plate archeopyle, but each can be distinguished from Hiddenocysta: Kiokansium (Duxbury 1983) has a smooth wall, simpler processes and a complete absence of tabulation; Taleisphaera (Masure 1986) has diagnostic penitabular crests; Pulchrasphaera (Schiøler et al. 1997) has low non-tabular ornamentation; Nexosispinum (Davey 1979) has anastomosing processes; Corradinium (Masure 1986) mainly has intratabular processes; Gongylodinium (Fenton et al. 1980) is non-tabulate and does not bear processes; and Occisucysta (Gitmez 1970) is characterized by a pronounced apical boss and denticulate or spiny sutural crests. The genera Durotrigia, Dissiliodinium and Cavatodissiliodinium have a multiplate precingular archeopyle but which most often involves more than two plates (Feist-Burkhardt and Monteil 2001). Furthermore, species of Dissiliodinium are characterized by negative structures (i.e., grooves), Cavatodissiliodinium is cavate, and Durotrigia species have ridges and septae, but no processes (Feist-Burkhardt and Monteil 2001).

Hiddenocysta matsuokae P Gurdebeke, V Pospelova, KN Mertens and S Louwye sp. nov. Pl. 1-3.

\section{Synonymy.}

Spiniferites sp. 1 Dobell and Taylor (1981), Pl. 1, Figs. 4, 11.

Spiniferites sp. 2 Dobell and Taylor (1981), Pl. 1, Figs. 9, 10, 12, 13, 16.

Spiniferites sp. Dobell and Taylor (1981), Pl., Figs. 14, 15, 19, 20.

Etymology. In honor of Dr. Kazumi Matsuoka, who made fundamental contributions to the taxonomy of dinoflagellates, mainly from the Pacific domain, specifically about cyst stages. 
Holotype. Kyuquot Sound (BC, Canada), core 2012002PGC133, slide UVic 2015-594-2 (870 cm core depth, 11 ka), EF Q42/1 (label left), Pl. 1, Figs. 1-6; Pl. 2, Fig. 1.

Repository. Royal Belgian Institute of Natural Sciences (RBINS, Brussels), accession $n^{\circ}$ IRSNB b7162.

Diagnosis. Cysts relatively large, spherical or slightly elongated, skolochorate. Wall granular and ornamented with numerous processes. Generally, gonal processes trifurcate and intergonal processes bifurcate. The distribution of the processes reflects a gonyaulacoid plate pattern. Process bases are hollow and periphragm heavily fenestrated. Neighboring processes can be connected by crests; mostly by a discrete lineation reflecting a septum or by an expanded periphragm that merges between two processes. One type of process is long, slender and trifurcate, with each of the three ends bifurcate and recurved. Other processes are shorter and broader with more expanded bases and also often trifurcate with bifurcate terminations. Distally from the pericoel, the processes are solid, but occasionally with one or more bubblelike structures along the length of the process shaft, above, below or at the trifurcation. Archeopyle compound, operculum involves two precingular plates ( $3^{\prime \prime}$ and $\left.4^{\prime \prime}\right)$ that release separately, and is free.

Dimensions. Holotype: central body $62 \times 51 \mu \mathrm{m}$; process length $14.8 \mu \mathrm{m}(\mathrm{N}=4)$. Forma 1 has a smaller central body and longer processes, whereas Forma 2 has a larger central body and shorter processes. The average sum of the central body diameter and process length is $\sim 71.9 \mu \mathrm{m}$ for Forma 1 and $\sim 71.2 \mu \mathrm{m}$ for Forma 2 . Central body wall is $\sim 1.1 \mu \mathrm{m}$ thick $(\mathrm{N}=3)$. For Forma 1, the height of the trifurcation above the process base is $\sim 7.7 \mu \mathrm{m}(\mathrm{N}=16)$. See Table 1.

Description. The cysts are spherical to ovoidal. The archeopyle margins follow the suture lines, and a projection from the apical margin of the archeopyle suggests $2 \mathrm{P}$ ( $\mathrm{Pl}$. 3, Fig. 1-3). These plates are of similar size; plates $3^{\prime \prime}$ is pentagonal and 4 " is quadrangular ( $\mathrm{Pl}$. 3, Fig. 1- 
2; see also Dobell and Taylor 1981). The cyst wall is granular on the outside and smooth on the inside (Pl. 2, Fig. 5), and an endophragm and periphragm can be distinguished (cf. Evitt 1985; Fig. 3). Near the processes, the phragma separate, and a pericoel forms the hollow process base. The periphragm lining the pericoel is heavily fenestrated ( $\mathrm{Pl}$. 1-3). Two morphological end-members can be defined within this species, and morphologies ranging between these end members were observed. The first end member (Forma 1; Fig. 3; Pl. 1, Fig. 1-6; Pl. 2, Fig. 1-2) has long and slender trifurcate processes terminating into recurved bifurcations resembling tendrils (cf. a Greek Ionian pillar). A single bubble-like structure is present below, at or above the trifurcation (Pl. 2, Fig. 1). The processes in Forma 1 are never connected by crests but by very low lineations only. The other end member (Forma 2; Fig. 3; Pl. 2, Fig. 2-9) has no clear single bubble-like structures as in Forma 1 but sometimes has numerous distributed small bubble-like structures in the processes (Pl. 2, Fig. 7); process bases are more expanded, more heavily fenestrated and are more often connected by the merging of the expanded periphragm at the respective process bases. There are more intergonal processes in Forma 2. There is no apparent heterogeneity in processes with respect to position on the cyst body. Distally from the pericoel, the process is solid, but in high magnification SEM micrographs of broken processes of Forma 1 (see Pl. 3, Fig. 6, indicated by an arrow), eight holes are visible, spread more or less evenly along the width of the process. It is unclear whether these are small bubble-like structures or canals running along the length of the processes. An apical boss is occasionally observed (Pl. 2, Fig. 2, 8), but appears not to be diagnostic. The cysts are often collapsed, folded and torn in palynologically prepared slides, which can also be observed when manipulating cysts (Pl. 2; Pl. 3, Figs. 4, 9, $10)$.

Remarks. Two end-members of this species were distinguished based on the process type. Specimens were observed bearing both types of processes, suggesting intraspecific variation. 
The species described here is identical to the specimens depicted by Dobell and Taylor (1981) based on size, tabulation, wall structure and the structure and organization of the processes.

Comparison. As it is the only species described in the genus Hiddenocysta, the comparison is as for the genus. The processes of $H$. matsuokae Forma 1 are often more slender than most Spiniferites species (Limoges et al. 2018; Mertens et al. 2018). Spiniferites solidago of de Verteuil and Norris (1996) has a comparable shape and the same characteristic vacuoles in the processes. However, this species differs from Hiddenocysta matsuokae by a 1P archeopyle, its wall ornamentation, its characteristic alveoles in the cyst wall and process terminations that are more simply bifurcate and do not resemble tendrils. Spiniferites lazus has similar perforations at the process base, but has a more elongated central body and a $1 \mathrm{P}$ archeopyle (Reid 1974; Gurdebeke et al., 2018b).

Distribution and biostratigraphy. The species is described here from estuarine waters of southwestern British Columbia and Vancouver Island (Canada), specifically from surface sediments of Hidden Basin ( $\sim 6 \mathrm{~m}$ water depth, sea surface temperature (SST) $7-16{ }^{\circ} \mathrm{C}$, sea surface salinity (SSS) 24-32 PSU, e.g., Gurdebeke et al. 2018a)) and as a present to rare species (up to $1.6 \%$ of the assemblage; terminology of Pospelova et al. 2004) throughout Holocene sediments of Kyuquot Sound ( 150 m water depth; Fig. 2; Supplementary Information Table 1). A specimen with endospore/cell content (Pl. 1, Fig. 1-6) was found in the early Holocene, $\sim 11 \mathrm{ka}$ (UVic 2015-594). This excludes reworking of the cysts, which is also improbable because of the local geology and hydrology of the fjord system (e.g., Muller et al. 1974) and because Dobell and Taylor (1981) successfully hatched similar cysts. The species was also observed in Ise Bay, Central Japan $\left(34^{\circ} 57.24^{\prime} \mathrm{N}, 136^{\circ} 43.84^{\prime} \mathrm{E}, 25 \mathrm{~m}\right.$ water depth; SST 10-23 ${ }^{\circ} \mathrm{C}$ and SSS 33-34 PSU, e.g., Narita et al. 2006) (K. Matsuoka, pers. comm.). From these limited observations, H. matsuokae occurs in ice-free estuaries with up to $150 \mathrm{~m}$ water depth in the temperate North Pacific. At present it is not clear whether Forma 1 
and 2 represent ecotypes, and if so, what is the driving environmental parameter. It is observed, however, that at the majority of the stratigraphic levels at which H. matsuokae is recorded in the Kyuquot Sound core, it is dominated by one Forma (Fig. 2).

Motile stage equivalent. Dobell and Taylor (1981) incubated cysts from surface sediments in Hidden Basin, which yielded dinoflagellates assignable to Gonyaulax, one of them they considered perhaps conspecific with Gonyaulax alaskensis, originally described by Kofoid (1911) and later restudied by Borgese (1987). Dobell and Taylor (1987) did note significant differences between their Gonyaulax sp. 1 and Gonyaulax alaskensis, particularly in size and cingular displacement. A relationship to G. alaskensis is interesting and would support a separate classification of this group of species from other Gonyaulax, initially proposed by Kofoid (1911). Kofoid (1911) placed G. alaskensis with G. fragilis in the subgenus Steiniella, separate from the typical Gonyaulax that have been related to Spiniferites. These latter were placed in the spinifera group of the subgenus Gonyaulax. Molecular phylogenies support such a separation: G. fragilis from the subgenus Steiniella (there is no sequence for G. alaskensis yet) is placed separately from a clade containing species from the spinifera group of the subgenus Gonyaulax, G. spinifera (sensu stricto) and G. digitale (Escalera et al. 2018; however see also Carbonell-Moore and Mertens, 2019). However, the situation is more complicated since G. polygramma is in the same clade as G. fragilis in the phylogenies; and Kofoid (1911) placed G. polygramma in the polygramma group of the subgenus Gonyaulax. It is also of interest to note that Ataxiodinium choanophorum can be found in the same clade as G. fragilis and G. polygramma (Mertens et al. 2017). New cyst-theca experiments with SEM-observations and molecular phylogenetics are needed to establish the correct cyst-theca relationship of this and related species.

\subsection{Chemical composition}


Micro-FTIR spectra were retrieved from three specimens from the core top sediment sample in Kyuquot Sound (UVic 2015-684) (Fig. 4). The absorption peak assignments are given in Table 2. The spectra show a broad absorption peak around $3275 \mathrm{~cm}^{-1}$, characteristic of $\mathrm{O}-\mathrm{H}$ stretching vibrations and two peaks at 2920 and $2860 \mathrm{~cm}^{-1}$ (C-H stretching). Within the fingerprint region, the main absorptions are centered at $\sim 1040 \mathrm{~cm}^{-1}$, with a second maximum around $1640 \mathrm{~cm}^{-1}$. The absorption spectra most closely resemble those of Spiniferites species (Gurdebeke et al. 2018b; spectrum of S. elongatus is shown in Fig. 4 for comparison) but differ in having a pronounced shoulder at $1540 \mathrm{~cm}^{-1}$ and in the region between 1500 and 1185 $\mathrm{cm}^{-1}$.

In all, the spectra reveal a cyst wall composition similar to those recorded for autotrophic taxa (e.g., Mertens et al. 2015, 2017; Gurdebeke et al., 2018b, Luo et al. 2018), which suggests a similar trophic preference for the motile stage that produces Hiddenocysta matsuokae sp. nov. This is in line with the morphology-based placement of this species with the Gonyaulacaceae, in which the majority of the species are autotrophic (e.g., Gaines and Elbrächter 1987; Gómez 2012b). In a PCA analysis comparing data from earlier studies (Gurdebeke et al. 2018b, 2019; Luo et al. 2018), the spectra for H. matsuokae form a distinct cluster confirming quantitatively the chemical distinctiveness of this species (Fig. 5). Also, the three spectra of $H$. matsuokae line up with other spectra of cysts of autotrophic taxa (Spiniferites, Bysmatrum, Prorocentrum) and are well separated from spectra of typical brown cysts of heterotrophic taxa (Quinquecuspis, Votadinium, Trinovantedinium pallidifulvum) (Fig. 5). The spectra for Trinovantedinium applanatum cysts are positioned intermediately (Fig. 5). These transparent cysts are produced by a heterotrophic species and were shown to have an aberrant wall composition compared with other cysts of heterotrophic dinoflagellates (Gurdebeke et al. 2019b). In all, the PCA analysis supports autotrophy for Hiddenocysta matsuokae. 


\section{Conclusions}

A new gonyaulacoid dinoflagellate cyst genus and species, Hiddenocysta matsuokae gen. nov., sp. nov., is described from Holocene sediments from Kyuquot Sound (Vancouver Island, BC, Canada). The species is presently known only from a few reports from estuarine sites in the northern Pacific Ocean. Cyst wall chemistry reveals a distinct macromolecular composition and supports the placement of $H$. matsuokae as an autotrophic within the Gonyaulacaceae. These results once more show the utility of micro-FTIR in the study of dinoflagellate cyst taxonomy and ecology. New incubation experiments and sequencing (e.g., ribosomal DNA sequences) are required to further evaluate the relationship with other gonyaulacoid species.

\section{Acknowledgements}

We are grateful to Dr. Audrey Dallimore for the sediment core collection and for sharing this material with us. Victor Pospelov and Alison Thomas are thanked for their help with sediment sampling and palynological preparation at the University of Victoria. VP acknowledges funding support from the Natural Science and Engineering Research Council of Canada (NSERC) Discovery Grant. The Regional Council of Brittany, the General Council of Finistère and the urban community of Concarneau-Cornouaille-Agglomération are acknowledged for the funding of the Sigma 300 FE-SEM of the station of Marine Biology in Concarneau, used in this study. The Research Foundation Flanders (FWO, Hercules Foundation) is thanked for funding the micro-FTIR facility (FT-IMAGER, project number AUGE/13/16), and also Henk Vrielinck for technical assistance and discussion of the microFTIR data. We thank Dr. Kazumi Matsuoka for sharing his observations from Japanese coastal waters. 


\section{References}

Bogus K, Mertens KNM, Lauwaert J, Harding IC, Vrielinck H, Zonneveld K, Versteegh GJM. 2014. Differences in the chemical composition of organic-walled dinoflagellate resting cysts from phototrophic and heterotrophic dinoflagellates. Journal of Phycology 50:254-266.

Borgese MB. 1987. Two armored dinoflagellates from the southwestern Atlantic Ocean: A new species of Protoperidinium and a first record and redescription for Gonyaulax alaskensis Kofoid. Journal of Protozoology 34:332-337.

Bringué M, Pospelova V, Calvert SE, Enkin RJ, Lacourse T, Ivanochko T. 2016. High resolution dinoflagellate cyst record of environmental change in Effingham Inlet (British Columbia, Canada) over the last millennium. Palaeogeography, Palaeoclimatology, Palaeoecology 441:787-810.

Carbonell-Moore MC, Mertens KN. 2019. Should Gonyaulax hyalina and Gonyaulax fragilis (Dinophyceae) remain two different taxa? Phycologia 58:6, 685-689.

Chomérat N, Couté A. 2008. Protoperidinium bolmonense sp. nov. (Peridiniales, Dinophyceae), a small dinoflagellate from a brackish hypereutrophic lagoon (South of France). Phycologia 47:392-403.

Davey RJ. 1979. Two new early Cretaceous dinocyst species from the northern North Sea. Palaeontology 22:427-437.

de Verteuil L, Norris G. 1996. Miocene dinoflagellate stratigraphy and systematics of Maryland and Virginia. Micropaleontology 42:1-172.

Dobell PER, Taylor FJR. 1981. Viable Spiniferites cysts with 2P archeopyles from Recent marine sediments, British Columbia, Canada. Palynology 5:99-106. 
Duxbury S. 1983. A study of dinoflagellate cysts and acritarchs from the Lower Greensand (Aptian to Lower Albian) of the Isle of Wight, southern England. Palaeontographica Abteilung B 186:18-80.

Escalera L, Italiano A, Pistocchi R, Montresor M, Zingone A. 2018. Gonyaulax hyalina and Gonyaulax fragilis (Dinoflagellata), two names associated with 'mare sporco', indicate the same species. Phycologia 57:453-464.

Evitt WR, 1985. Sporopollenin dinoflagellate cysts. Their morphology and interpretation. American Association of Stratigraphic Palynologists, 333 pp

Feist-Burkhardt S, Monteil E. 2001. Gonyaulacacean dinoflagellate cysts with multi-plate precingular archaeopyle. Neues Jahrbuch für Geologie und Paläontologie Abhandlungen 219:33-81.

Fenton JPG, Neves R, Piel KM. 1980. Dinoflagellate cysts and acritarchs from upper Bajocian to middle Bathonian strata of central and southern England. Palaeontology 23:151-170.

Gaines G, Elbrächter M. 1987. Heterotrophic nutrition. In: Taylor FJR (Ed.) The Biology of Dinoflagellates. Blackwell, pp. 398-503.

Gitmez GU. 1970. Dinoflagellate cysts and acritarchs from the basal Kimmeridgian (upper Jurassic) of England, Scotland and France. Bulletin of the British Museum of Natural History (Geology) 18:231-331.

Gómez F. 2012a. A checklist and classification of living dinoflagellates (Dinoflagellata, Alveolata). CICIMAR Oceanides 27:65-140.

Gómez F. 2012b. A quantitative review of the lifestyle, habitat and trophic diversity of dinoflagellates (Dinoflagellata, Alveolata). Systematics and Biodiversity 10, 267275. 
Gurdebeke PR. 2019. Holocene dinoflagellate cysts and other palynomorphs from Northern Hemisphere estuaries. Taxonomy, distribution, geochemistry and paleoecological application. PhD thesis, Ghent University, Ghent, Belgium.

Gurdebeke PR, Pospelova V, Mertens KN, Dallimore A, Chana J, Louwye S. 2018a. Diversity and distribution of dinoflagellate cysts in surface sediments from fjords of western Vancouver Island (British Columbia, Canada). Marine Micropaleontology $143: 12-29$.

Gurdebeke PR, Mertens KN, Bogus K, Marret F, Chomérat N, Vrielinck H, Louwye S. 2018b. Taxonomic re-investigation and geochemical characterization of Reid's (1974) species of Spiniferites from holotype and topotype material. Palynology 42 (S1):93-110.

Gurdebeke PR, Mertens KN, Pospelova V, Van Nieuwenhove N, Louwye S. 2019a. Islandinium pacificum sp. nov., a new dinoflagellate cyst from the upper Quaternary of the northeast Pacific. Palynology https://doi.org/10.1080/01916122.2018.1549118

Gurdebeke PR, Mertens KN, Pospelova V, Matsuoka K, Li Z, Gribble KE, Gu H, Bogus K, Vrielinck H, Louwye S. 2019b. Taxonomic revision, phylogeny, and cyst wall composition of the dinoflagellate cyst genus Votadinium Reid (Dinophyceae, Peridiniales, Protoperidiniaceae). Palynology, https://doi.org/10.1080/01916122.2019.1580627.

Head MJ. 1996. Chapter 30. Modern dinoflagellate cysts and their biological affinities. In: Jansonius J, McGregor DC (Eds.), Palynology: principles and applications. Vol. 3. American Association of Stratigraphic Palynologists Foundation, 1197-1248.

Kofoid CA. 1911. Dinoflagellata of the San Diego Region, IV. The genus Gonyaulax with notes on the skeletal morphology. University of California Publications in Zoology 8:187-287. 
Kokinos JP, Eglinton TI, Goñi MA, Boon JJ, Martoglio PA, Anderson DM. 1998. Characterization of a highly resistant biomacromolecular material in the cell wall of a marine dinoflagellate resting cyst. Organic Geochemistry 28:265-288.

Krepakevich A, Pospelova V. 2010. Tracing the influence of sewage discharge on coastal bays of Southern Vancouver Island (BC, Canada) using sedimentary records of phytoplankton. Continental Shelf Research 30:1924-1940.

Kumar A, Patterson RT. 2002. Dinoflagellate cyst assemblages from Effingham Inlet, Vancouver Island, British Columbia, Canada. Palaeogeography, Palaeoclimatology, Palaeoecology 180:187-206.

Limoges A, Londeix L, Mertens KN, Rochon A, Pospelova V, Cuéllar T, de Vernal A. 2018. Identification key for Pliocene and Quaternary Spiniferites taxa bearing intergonal processes based on observations from estuarine and coastal environments. Palynology 42 (S1):72-88.

Londeix L, Zonneveld K, Masure E, 2018. Taxonomy and operational identification of Quaternary species of Spiniferites and related genera. Palynology 42(S1):45-71.

Luo Z, Lim ZF, Mertens KN, Gurdebeke PR, Bogus K, Carbonell-Moore MC, Vrielinck H, Leaw CP, Lim PT, Chomérat N, Li X, Gu H. 2018. Morpho-molecular diversity and phylogeny of Bysmatrum (Dinophyceae) from the South China Sea and France. European Journal of Phycology 53:318-335.

Masure E. 1986. Corradinisphaeridinium, nouveau genre de dinoflagellés du Sénonien d'Italie et de France. Revue de Micropaléontologie 29:109-119.

Mertens KN, Carbonell-Moore C. 2018. Introduction to Spiniferites Mantell 1850 special issue. Palynology 42 (S1):1-9.

Mertens KN, Yamaguchi A, Kawami H, Ribeiro S, Leander BS, Price AM, Pospelova V, Ellegaard M, Matsuoka K. 2012b. Archaeperidinium saanichi sp nov.: a new species 
based on morphological variation of cyst and theca within the Archaeperidinium minutum Jorgensen 1912 species complex. Marine Micropaleontology 96-97:48-62.

Mertens KN, Yamaguchi A, Takano Y, Pospelova V, Head MJ, Radi T, Pienkowski AJ, de Vernal A, Kawami H, Matsuoka K. 2013. A new heterotrophic dinoflagellate from the North Pacific, Protoperidinium fukuyoi: cyst-theca relationship, phylogeny, distribution and ecology. Journal of Eukaryotic Microbiology 60:545-563.

Mertens KN, Takano Y, Gu H, Bagheri S, Pospelova V, Pieńkowski AJ, Leroy S, Matsuoka K. 2017. Cyst-theca relationship and phylogenetic position of Impagidinium caspienense incubated from Caspian Sea surface sediments: evidence for heterospory within gonyaulacoid dinoflagellates. Journal of Eukaryotic Microbiology 64:829_ 842.

Mertens KN, Van Nieuwenhove N, Gurdebeke PR, Aydin H, Bogus K, Bringué M, Dale B, De Schepper S, de Vernal A, Ellegaard M et al.2018. Summary of round table discussions about Spiniferites and Achomosphaera occurring in Pliocene to modern sediments. Palynology. 42(S1):10-44.

Mudie PJ, Rochon A, Levac E. 2002. Palynological records of red-tide producing species in Canada: past trends and implications for the future. Palaeogeography, Palaeoclimatology, Palaeoecology 180:159-186.

Narita T, Ganmanee M, Sekiguchi H. 2006. Population dynamics of a dragonet Repomucenus valenciennei in Ise Bay, central Japan. Nippon Suisan Gakkaishi 72:860-872.

Patterson RT, Prokoph A, Kumar A, Chang AS, Roe HM. 2005. Late Holocene variability in pelagic fish scales and dinoflagellate cysts along the west coast of Vancouver Island, NE Pacific Ocean. Marine Micropaleontology 55:183-204.

Patterson RT, Swindles GT, Roe HM, Kumar A, Prokoph A. 2011. Dinoflagellate cyst-based reconstructions of mid to late Holocene winter sea-surface temperature and 
productivity from an anoxic fjord in the NE Pacific Ocean. Quaternary International 235:1325.

Penaud A, Hardy W, Lambert C, Marret F, Masure E, Servais T, Siano R, Wary M, Mertens KN. 2018. Dinoflagellate fossils: Geological and biological applications. Révue de Micropaléontologie 61, 235-254.

Pospelova V, Chmura GL, Walker HA. 2004. Environmental factors influencing the spatial distribution of dinoflagellate cyst assemblages in shallow lagoons of southern New England (USA). Review of Palaeobotany and Palynology 128:7-34.

Pospelova V, Esenkulova S, Johannessen SC, O'Brien MC, Macdonald RW. 2010. Organicwalled dinoflagellate cyst production, composition and flux from 1996 to 1998 in the central Strait of Georgia (BC, Canada): A sediment trap study. Marine Micropaleontology 75:17-37.

Price AM, Pospelova V. 2011. High-resolution sediment trap study of organic-walled dinoflagellate cyst production and biogenic silica flux in Saanich Inlet (BC, Canada). Marine Micropaleontology 80:18-43.

Price AM, Gurdebeke PR, Mertens KN, Pospelova V. 2016a. Determining the absolute abundance of dinoflagellate cysts in recent marine sediments III: Identifying the source of Lycopodium loss during palynological processing and further testing of the Lycopodium marker-grain method. Review of Palaeobotany and Palynology 226:7890.

Radi T, Pospelova V, de Vernal A, Barrie JV. 2007. Dinoflagellate cysts as indicators of water quality and productivity in British Columbia estuarine environments. Marine Micropaleontology 62:269-297. 
Schiøler P, Brinkhuis H, Roncaglia L, Wilson GJ. 1997. Dinoflagellate biostratigraphy and sequence stratigraphy of the Type Maastrichtian (Upper Cretaceous), ENCI Quarry, the Netherlands. Marine Micropaleontology 31:65-95.

Van Nieuwenhove N, Potvin E, Heikkilä M, Pospelova V, Mertens KN, Masure E, Kucharska M, Yang EJ, Chomérat N, Zajaczkowski M. 2018a. Taxonomic revision of Spiniferites elongatus (the resting stage of Gonyaulax elongata) based on morphological and molecular analyses. Palynology 42 (S1):111-134.

Versteegh GJM, Blokker P, Bogus K, Harding IC, Lewis J, Oltmanns S, Rochon A, Zonneveld KAF. 2012. Flash pyrolysis and infrared spectroscopy of cultured and sediment derived Lingulodinium polyedrum (Dinoflagellata) cyst walls. Organic Geochemistry 43:92-102.

Wilson GJ. 1973. Palynology of the middle Pleistocene Te Piki Bed, Cape Runaway, New Zealand. New Zealand Journal of Geology and Geophysics 16:345-354. 

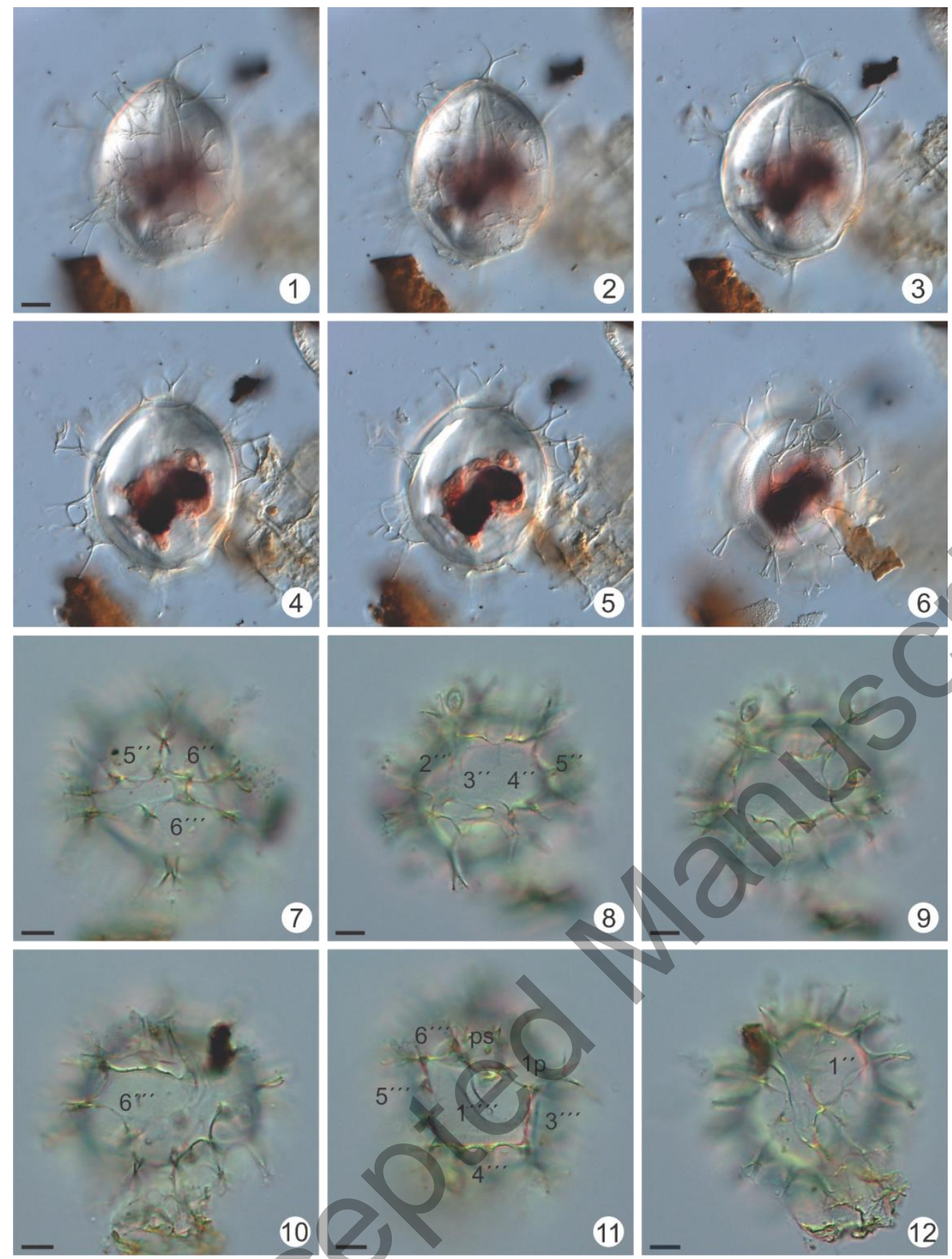

Plate 1. 1-12. Hiddenocysta matsuokae gen. nov. et sp. nov. from core 2012002PGC133. 16. Forma 1; Holotype, Kyuquot Sound, UVic 2015-594-2, EF Q42/1. High to low focus. 7-12. Forma 1, Kyuquot Sound, manually picked from UVic 2015-609 residue, with indication of tabulation; 8 and 9 show the archeopyle. Scale bar $=10$ $\mu \mathrm{m}$. 

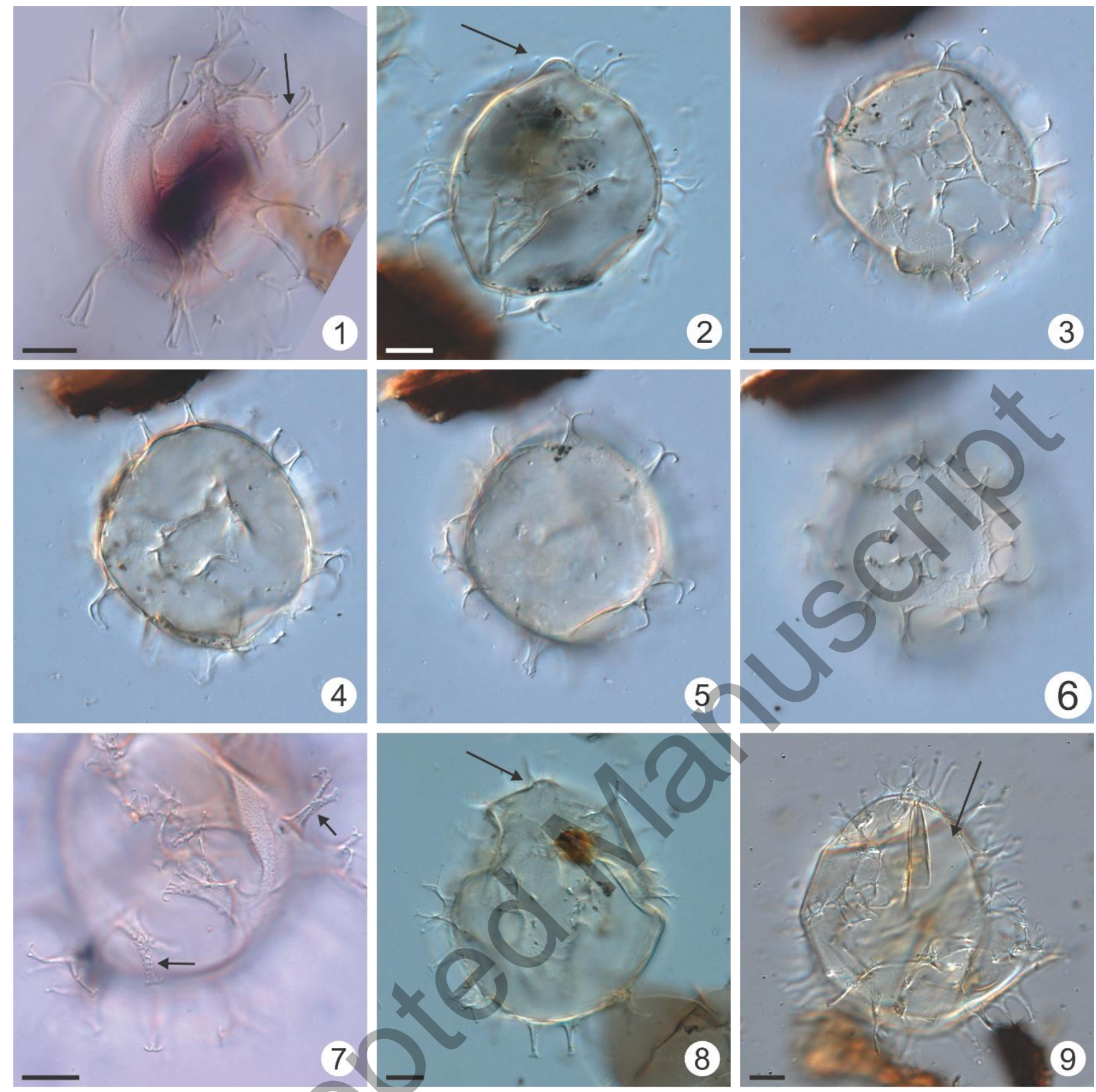

Plate 2. 1-9. Hiddenocysta matsuokae gen. nov. et sp. nov. from core 2012002PGC133. 1-2:

Forma 1. 1: Holotype, Kyuquot Sound, UVic 2015-594-2, EF Q42/1; arrow is pointing at vacuole; 2: UVic 2015-607-2, optical section, apical boss is marked by arrow. 3-9: Forma 2. 3-6: UVic 2015-596-2: high to low focus; 7: UVic 2015-596-2, focus on numerous vacuoles, indicated by arrows. 8: UVic 2015-607-2, arrow indicating apical boss. 9: UVic 2015-613-2, possible archeopyle is shown by arrow. All scale bars $=10 \mu \mathrm{m}$. 


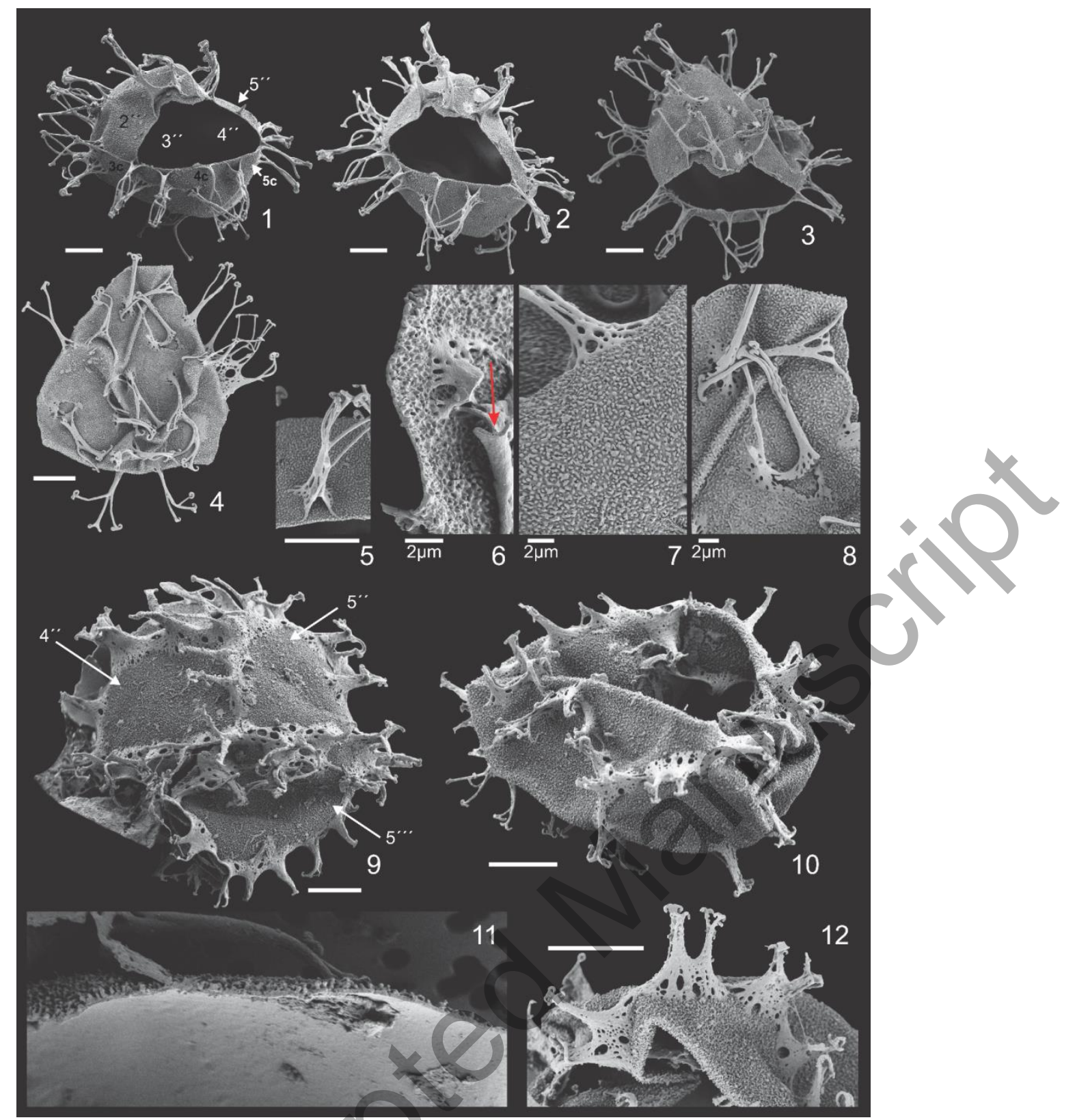

Plate 3. FE-SEM images of Hiddenocysta matsuokae sp. nov., Kyuquot Sound core 2012002PGC133, UVic 2015-609. 1-8. Forma 1; 1-3: ambitus with archeopyle and showing the tabular arrangement of the processes; 4: typical crushed specimen; 5: detail of process; 6 : detail of broken process, with arrow indicating small structures within the process; $7-8$ : details of wall and process structures. 9-12. Forma 2; 9-10: crushed ambitus, showing the tabular arrangement of the processes, which are often connected by low crests and bear intergonals; 11: detail of wall structure; 12: detail of processes. Tabulation is indicated in 1 and 9. All scale bars $=10 \mu \mathrm{m}$ unless indicated otherwise. 


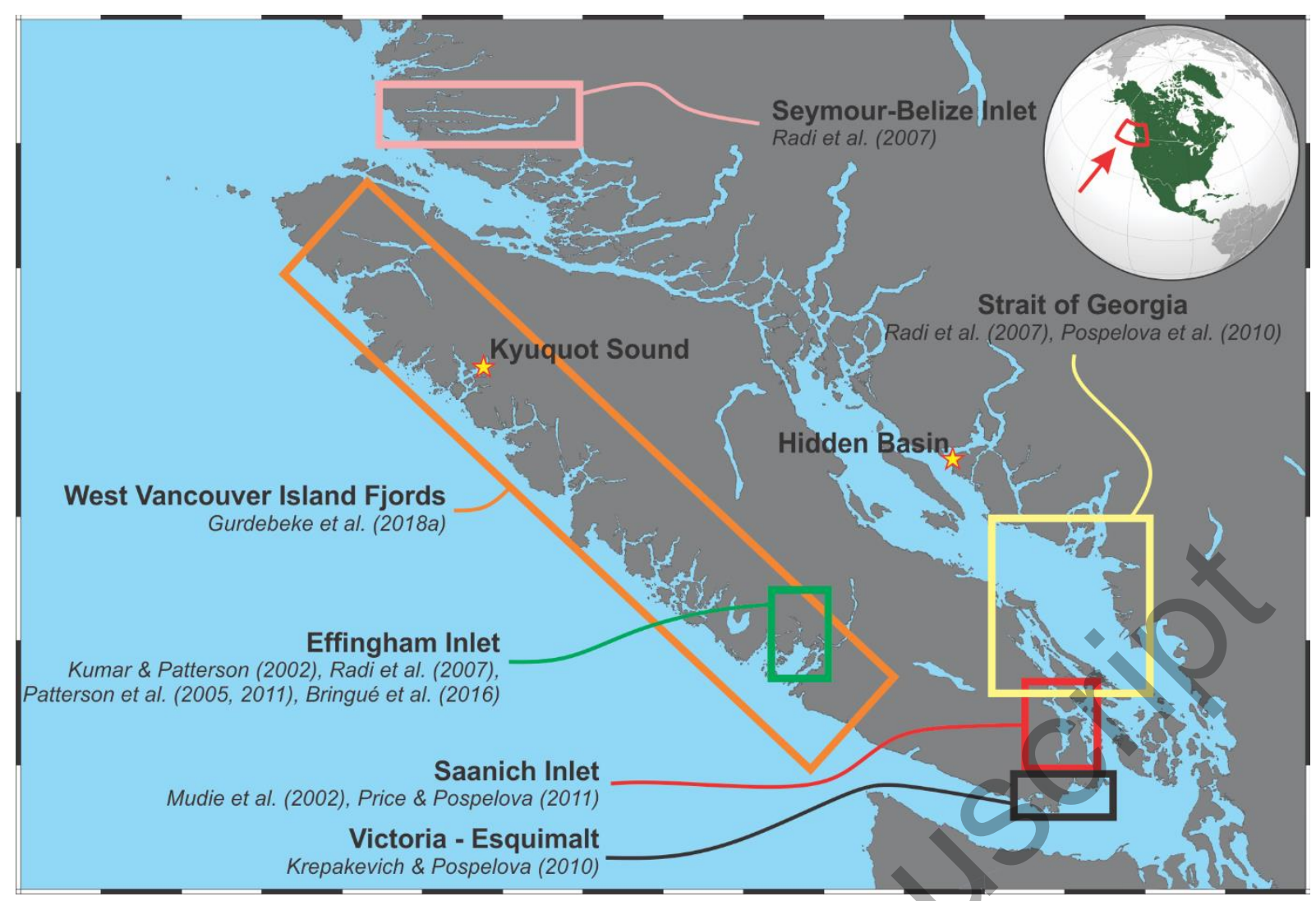

Fig. 1. Map of Vancouver Island, with indication of study areas of previous studies on dinoflagellate cyst distribution, with indication of both localities where Hiddenocysta matsuokae sp. nov. is found: Kyuquot Sound and Hidden Basin (yellow stars). 


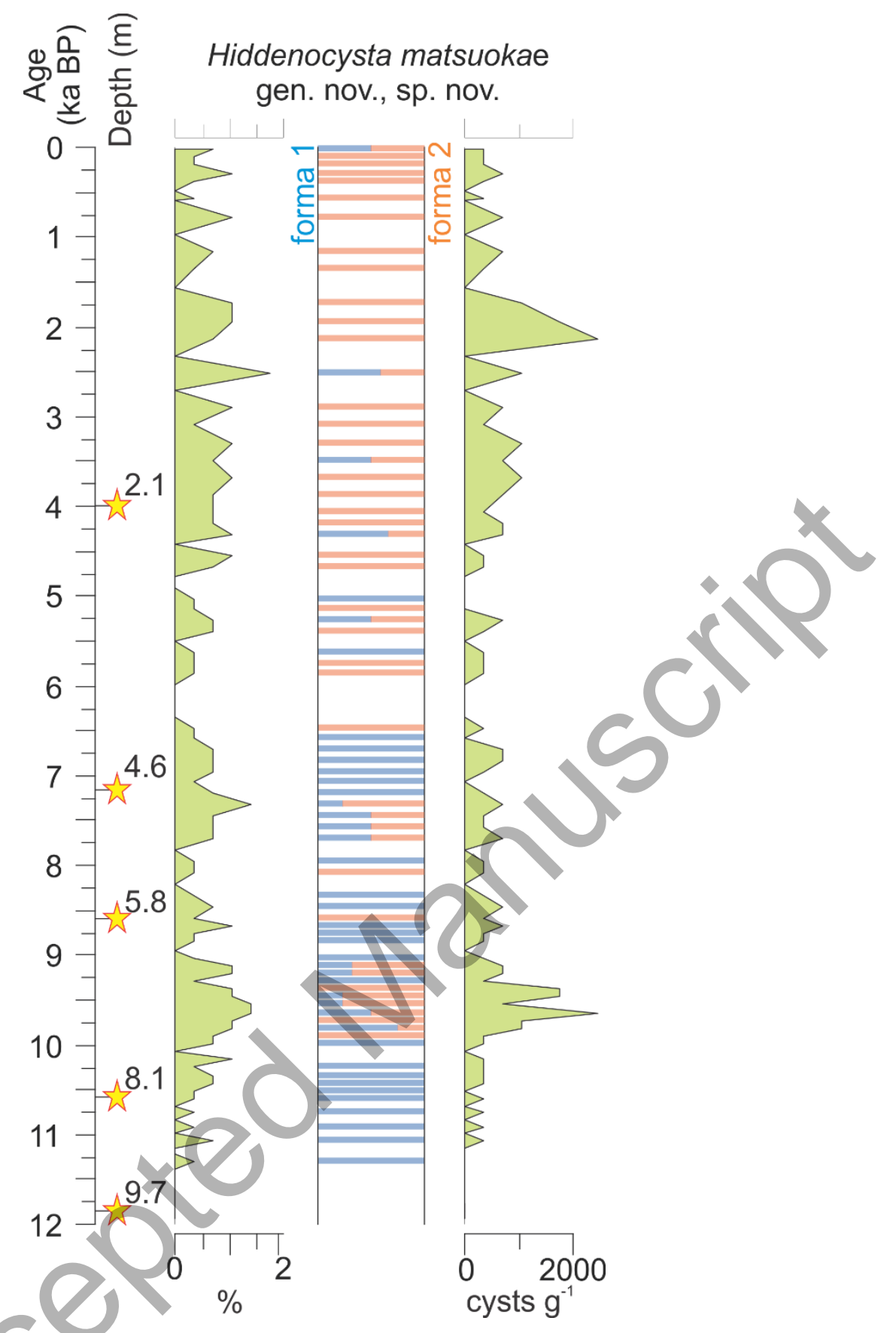

Fig. 2. Diagram showing the downcore relative and absolute abundance of Hiddenocysta matsuokae sp. nov. in core 2012002PGC133. A total of 146 specimens was observed in the core record (Supplementary Information Table 1). Yellow stars indicate the levels of radiocarbon dating (Gurdebeke 2019). Blue and orange bars indicate the proportions of Forma 1 and 2 respectively. 


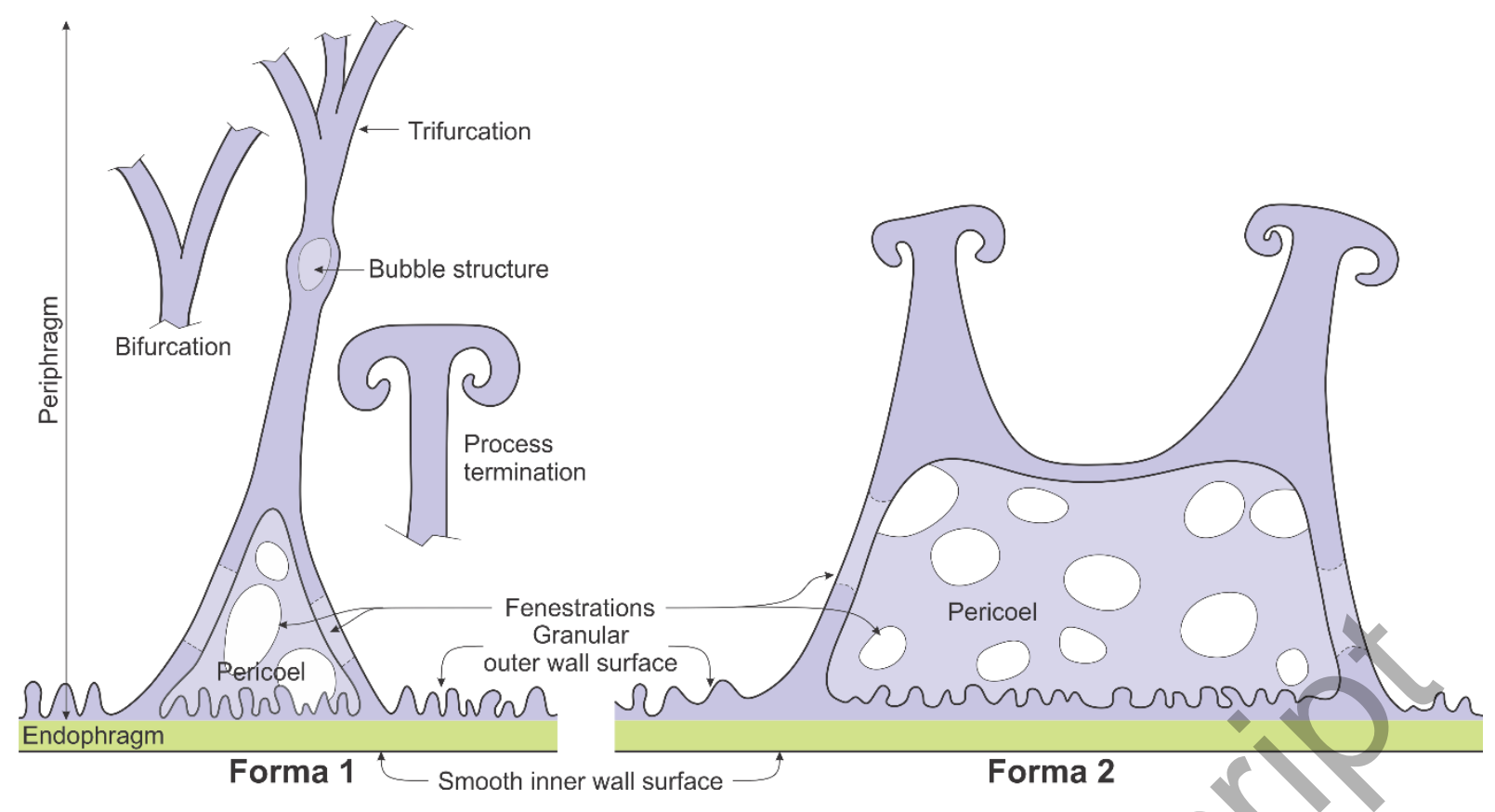

Fig. 3. Schematic representation of a cross section of wall and process structure of Hiddenocysta matsuokae sp. nov., Forma 1 (left) and Forma 2 (right). 


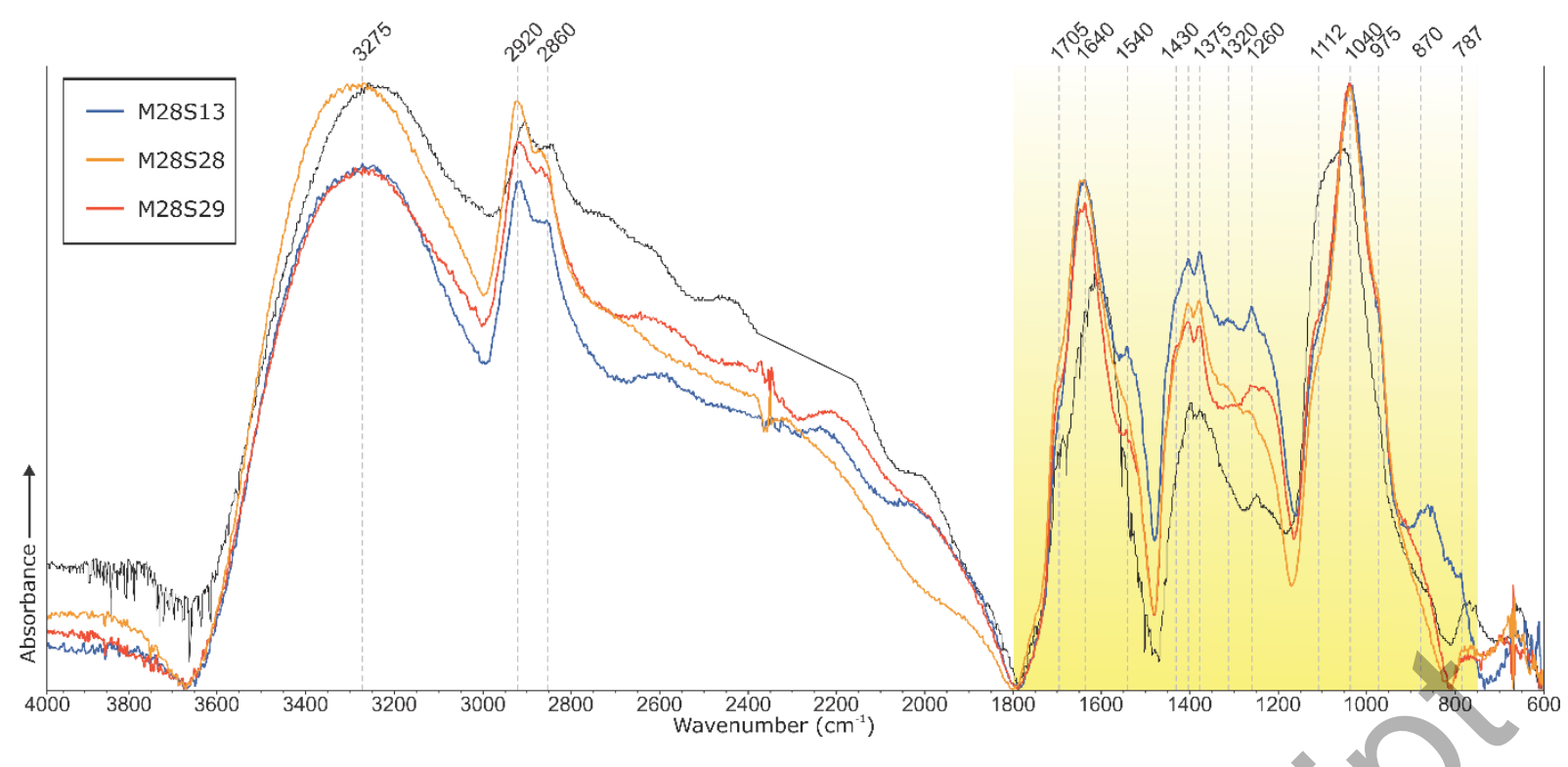

Fig. 4. Micro-FTIR spectra of three specimen of Hiddenocysta matsuokae sp. nov., with indication of major absorption peaks (see Table 2). For comparison, the thin black line is the spectrum of Spiniferites elongatus from Dee Estuary (U.K.) described by Gurdebeke et al. (2018b). The shaded region delineates the fingerprint region. 


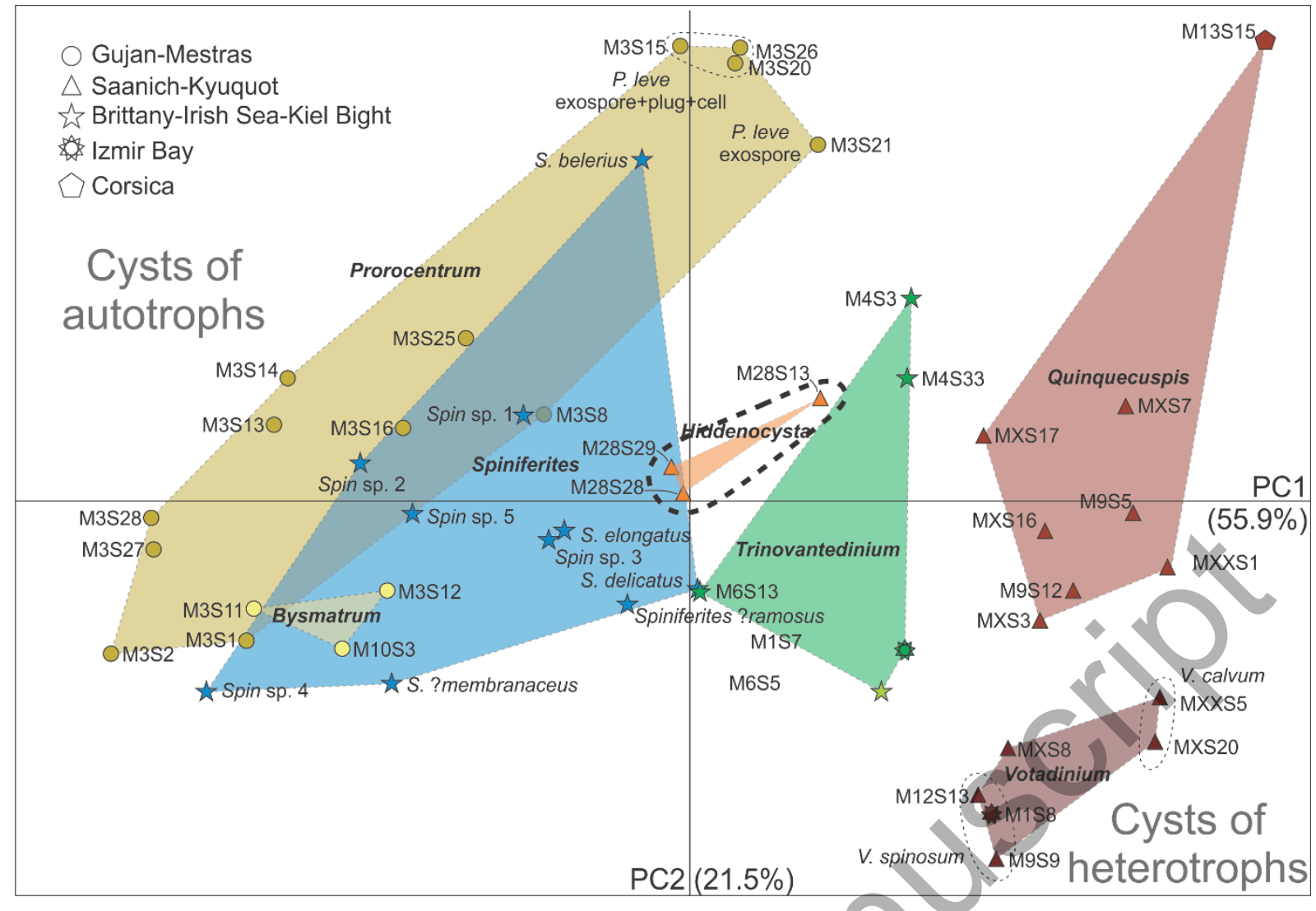

Fig. 5. PCA plot (PC1-2) of fingerprint region of three Hiddenocysta matsuokae sp. nov. spectra (M28S13, M28S28 and M28S29) compared with cyst wall spectra at various locations from earlier studies: 13 Prorocentrum leve spectra (Mertens et al. 2017), 3 Bysmatrum subsalsum spectra (Luo et al. 2018), 8 Spiniferites spectra (1 S. belerius, 1 S. ?membranaceus, 3 S. ?ramosus, 1 S. delicatus, 1 S. elongatus, 5 Spiniferites spp.; Gurdebeke et al. 2018b), 6 Votadinium spectra (3 V. spinosum, 1 V. pontifossatum, 2 V. calvum; Gurdebeke et al. 2019b), 8 Quinquecuspis concreta spectra (Gurdebeke et al. 2019b) and 5 Trinovantedinium spectra (1 T. pallidifulvum, 4 T. applanatum; Gurdebeke et al. 2019b). 
Table 1. Morphometrics of Hiddenocysta matsuokae sp. nov.

\begin{tabular}{|c|c|c|c|c|c|c|}
\hline & Min & Max & Average & Median & $\mathrm{SD}$ & $\mathrm{N}$ \\
\hline \multicolumn{7}{|l|}{ a) Overall } \\
\hline Central body diameter $(\mu \mathrm{m})$ & 45.4 & 69.8 & 58.1 & 56.9 & 7.1 & 20 \\
\hline Process length $(\mu \mathrm{m})$ & 6.6 & 24.3 & 13.5 & 12.6 & 4.5 & 40 \\
\hline \multicolumn{7}{|l|}{ b) Forma 1} \\
\hline Central body diameter $(\mu \mathrm{m})$ & 45.4 & 63.4 & 55.4 & 55.1 & 5.6 & 10 \\
\hline Process length $(\mu \mathrm{m})$ & 12.5 & 24.3 & 17.1 & 16.2 & 3.1 & 20 \\
\hline \multicolumn{7}{|l|}{ c) Forma 2} \\
\hline Central body diameter $(\mu \mathrm{m})$ & 47.8 & 69.8 & 60.9 & 64.6 & 7.4 & 10 \\
\hline Process length $(\mu \mathrm{m})$ & 6.6 & 12.6 & 9.8 & 9.9 & 1.9 & 20 \\
\hline
\end{tabular}

Table 2. Micro-FTIR assignments of functional groups present in the spectra of Hiddenocysta matsuokae sp. nov.

\begin{tabular}{|l|l|l|}
\hline Wavenumber $\left(\mathrm{cm}^{-1}\right)$ & Assignment & Comment \\
\hline $3265-3285$ & $v \mathrm{O}-\mathrm{H}$ & \\
\hline 2920 & $v \mathrm{C}-\mathrm{H}$ & \\
\hline 2865 & $v \mathrm{C}-\mathrm{H}$ & \\
\hline 1705 & $v \mathrm{C}=\mathrm{O}$ & shoulder \\
\hline 1640 & $v \mathrm{C}=\mathrm{O}$ & \\
\hline 1540 & Amide II & \\
\hline 1430 & $\delta \mathrm{CH} 2$ & \\
\hline 1375 & $\delta \mathrm{CH}+\delta \mathrm{C}-\mathrm{CH} 3$ & \\
\hline 1280,1320 & $\delta \mathrm{OH}$ & \\
\hline 1112 & $v \mathrm{C}-\mathrm{O}$ & glucose ring, shoulder \\
\hline 1040 & $v \mathrm{C}-\mathrm{O}$ & \\
\hline
\end{tabular}

